\title{
Drivers for Smart Servitization in Manufacturing Companies
}

\author{
Lucie Kaňovská1, Eva Tomášková \\ ${ }^{1}$ Faculty of Business and Management, Brno University of Technology, Brno, Czech Republic \\ ${ }^{2}$ Faculty of Law, Masaryk University, Brno, Czech Republic
}

\begin{abstract}
Wireless communication technologies associated with the Internet of things (IoT) have started to be used also in manufacturing. Developing data-driven services by IoT also known as "smart services" in manufacturing business has become one of the current trends. Sensors enable IoT systems to provide intelligent and smart services during the shift towards smart production. Smart technologies have begun to be used also in agriculture by means of agricultural and farming applications. The aim of the paper is to determine why manufacturing companies have started to provide smart services with their products. A literature review presents the background of smart services in manufacturing companies as well in agriculture. For the empirical part, a qualitative multi-case study was conducted among seven Czech electrotechnical manufacturers and one Czech agricultural tractor manufacturer. All case companies have already begun with their smart service development. The findings indicate that manufactures usually decide by themselves to start with smart servitization, but the main categories of smart servitization drivers are connected to competitive advantage. The study is unique in highlighting the problems of smart services in SMEs in the Czech Republic, where the industrial sector is still dominant in comparison to other European countries.
\end{abstract}

\section{Keywords}

Smart servitization, smart services, electrotechnical and agricultural manufacturers, smart (precision) agriculture (farming), Czech Republic.

Kaňovská, L. and Tomášková, E. (2018) "Drivers for Smart Servitization in Manufacturing Companies", AGRIS on-line Papers in Economics and Informatics, Vol. 10, No. 3, pp. 57-68. ISSN 1804-1930. DOI 10.7160/aol.2018.100305.

\section{Introduction}

Many manufacturers deliver not only tangible products to their customers, but also provide services accompanying their products. Industrial companies are offering product-related services throughout the product lifecycle due to the increasing input costs and competition (Herterich et al., 2015). Such service-oriented practise is described as "servitization", a practise becoming inevitable among manufacturers which no longer offer tangible products without accompanying services customized to suit the customer needs (Baines et al., 2009). The first beginning of servitization in manufacturing could be seen in $1800 \mathrm{~s}$, when International Harvester used services to help bringing their new reaping equipment to farmers located in the American Midwest (Baines and Lightfoot, 2013).

Some manufactures use data-driven services by the Internet of Things (IoT), also known as "smart services". Smart services are important for both manufacturing companies as service providers as well as for their customers. Service can improve value creation and profitability for both the business and customers. The beginning of smart service provision is not easy, especially in SMEs (small and medium-sized enterprises) where many enterprises struggle with lack of money, insufficient digital technologies or unskilled employees. Large companies may assume very complicated and challenging tasks. The agricultural manufacturers also implement the IoT related technologies to be able to deliver services which can track crop environments to optimize crop yields and develop sustainable outcomes (Cedeño et al., 2018).

Most of agriculture is directly driven by weather, consequently "holy grail" of smart or precision agriculture is accurate, automated and continuous weather forecast (Bőgel, 2017). However, an increasing number of manufacturers are beginning to add smart services to their offers. Their motivations to start with smart service 
provision could be based on competition, demand and economic motives. Motivations to servitize vary according to product complexity, although cost savings and improved service quality appear important demand-based motivations for all manufacturers (Raddats at el., 2016).

Some researchers have already studied service transformation in manufacturing companies, but there are not many analyses that focus on the impact of ICT on industrial services. To fill the void, the paper presents the investigation into why manufacturing companies have started to provide smart services to their products. A qualitative multi-case study was conducted among seven Czech electrotechnical SMEs and one Czech manufacturer of tractors. All case companies have already started with smart service development. The findings show that manufactures usually decide by themselves to start with smart servitization, but the main categories of smart servitization drivers are connected to competitive advantage.

\section{Theoretical background}

Companies in manufacturing industries, including production of agricultural equipment (such as tractors, harvesters, trailers), encounter various challenges. In particular, competition in terms of cost and technology leadership has increased with the commodization of products (Lim et al., 2015). Thus, numerous companies have adopted a service-led competitive strategy to distinguish themselves from competitors. Literature calls this trend "servitization" (Baines et al., 2009). Manufacturing industry participants are more concerned in offering customized services such as maintenance, repair, training, overhauling, and technical supporting, commonly known as "servitization in manufacturing" (Lightfoot et al., 2013).

\section{Smart Servitization}

It is widely agreed that technology is behind the rapid progress of today's service driven economy. Smart servitization or "smartization" is considered a new level of interconnected intelligence including automatic processes and data transformation extending the scope of product related services companies can offer. Some consider ICT essential to an increasing number of services and argue that the rise of services and the information revolution are inseparable (Rust et al., 2014). The area of smart servitization has not been properly researched yet as the scarce research projects focused on one specific digital technology at a time excluding the influence of all relevant technologies. According to Grubic and Jennions (2017), more thorough investigation and systematization of the existing knowledge is necessary.

The technological advancement including cloud manufacturing, IoT, online analytics and additive manufacturing resulted into an interconnected world. The rapid ICT development allowed businesses to apply innovative strategies and unique business models to better satisfy their customers.

Some manufactures develop data-driven services by the Internet of Things (IoT), also known as "smart services". The term "Internet of Things" (IoT) means a "global network infrastructure where physical and virtual objects are discovered and integrated seamlessly" (Kiritsis, 2011). The "IoT" is growing faster than the "internet of people" because billions of cars, production tools, household devices, sensors, etc. All will be connected to the network in the near future. Furthermore, connectivity and data will get cheap and globally accessible (Bögel, 2017).

Smart services are defined as services tailored to specific customer needs with the help of data and intelligent processing (Hermann et al., 2016). Therefore, it is essential to understand the customers and their surroundings, to have smart data and platforms to integrate and process the data and to change the business models and company mindset (Marquardt, 2017). IT technologies help to gain quality and timely information for the success of both large and small companies. Šilerova et al. (2017) mention that it would be worthwhile for the IT department to monitor the impact of the usage of information system on the business results as well as the competitiveness of the company, goodwill, social situation in the company, cooperation with the suppliers, and the customers. Knowledge in the field of information and communication technologies has become an essential condition for the success of managers in all areas of economic activity (Hallová, 2017). Smart services are often seen as one of the enablers of servitization (e.g. Neu and Brown, 2005; Oliva and Kallenberg, 2003). According to Allmendinger and Lombreglia (2005): "Soon, it will not be enough for a company to offer services; it will have to provide "smart services"".

The terminology related to smart services has not been unified yet. There are many definitions of smart services such as as 'teleservice' (Borgmeier, 2002), 'tele-maintenance' (Garcia et al., 2004), 'telematics' (Chatterjee et al., 2001), 'e-service' 
(Rowley, 2006), 'e-maintenance' (Levrat et al., 2008) or some variations using the term 'remote', such as 'RRDM (Remote Repair, Diagnostics and Maintenance)'. However, the term 'smart service' has been prevailing (Klein, 2017). Klein (2017, p. 8) describes smart services as "Smart services are technologically-mediated services actively delivered by the provider through accessing a remote asset and exchanging data through builtin control and/or feedback devices." Beverungen et al. (2017) define smart service as "the application of specialized competences, through deeds, processes, and performances that are enabled by smart products".

The farming industry is not as exemption of the smart servitization era nowadays. The agriculture industry is changing towards the IoT. This could be called as "Precision" or "Smart" farming". The current crop environment is tracked by "Smart Devices" and all the productive units interacting with it. For agri-food businesses, it is a new trend, which offers multiple occasions for optimizing crop yield and providing sustainable products and services (Cedeño et al., 2018).

\section{Smart services in agriculture}

Agriculture is a sector in the early phase of its digital transition. Farmers and manufactures of agriculture machines, such as harvesters and tractors, should study how to build and manage smart systems, how to acquire and harness digital capabilities and how to collaborate and compete in the current environment (Bőgel, 2017).

The term precision agriculture, together with GPSguided tractors, also appeared in the early 1990s. Its fundamental principles were well known by farmers since the early days of agriculture (Brase, 2005). Precision agriculture developed at varying pace geographically (Zhang et al., 2002). France were the door openers in Europe, just like Argentina and Brazil in South America. Despite early efforts, the sector's digital progress was slow. It takes time to asses and evaluate the short and longterm effects of this kind of innovation, but we can assume that it will follow the same trajectory as that of other industries, but apparently slower. Industry observers express the concern that adoption of agricultural software solutions is slow, penetration is much lower than predicted, digital systems' capabilities are underutilized, many producers use them only to prepare simple tables, to-do-lists and working schedules (Bögel, 2017).

Cedeno et al. (2018) identified two customer needs addressed by smart services intending to optimize tractor-implement operations. Following is the description of the needs identified. First, farmers need to implement integration with tractors - Smart services to address this need include product system (highly integrated tractor with implements for optimal operations, optimization of equipment operations (implement operation optimized based on historic operation data), remote diagnosis (diagnosis accomplished remotely through remote service centers), remote repairing (non-complex repairs made by remote service centers), predictive services (trigger service activities based on current component condition), and real-time simulations (simulation different tractors - implement operation for prototyping and testing purposes). Second, the work plan elaboration needs to be more efficient. Following smart services are at disposal to address this need: automatic work plan generator (generates work plans according to current progress and available resources), real-time project manager (tracks current progress, forecasts potential delivery times and resources consumption based on historic data).

For products such as farming machines, tractors, diggers, and hoisting machinery, there is a great potential for fuel economy when operating them with the IoT support. A FireFly Equipment turfgrass slab harvester, for example, is able to save up to $50 \%$ of its fuel because it may be operated almost all-day long. (National Instruments, 2018). The following examples of manufactures show the presence of smart service technologies in their products.

Valtra is a manufacturer and service provider in the Nordic countries and Valtra machines are sold in over 75 countries. Their System Valtra Connect transmits tractor data to smart phones and computers. Data are accessible to both customers and to customer service centers (Valtra, 2018).

Tractors and some other machines manufactured by John Deere are able to report, monitor, and control machine operations through telematics promises to revolutionize heavy machinery-based industries. The benefits could be seen in the efficient logistics, reduced maintenance, and cost control. Their products can provide a system that fits customer specific needs by using of Components that are designed and manufactured to withstand severe temperature, vibration, and sealing requirements (John Deere, 2018).

Products branded by New Holland provide New Holland's PLM ${ }^{\circledR}$ solutions for their customers. 
A comprehensive software package enables to manage all aspects of farm to enhance productivity and reduce soaring input costs. Telematics technology enables fleet managers to connect to their machines from the comfort of their office. Customers can send and receive real-time information that saves time and enhances productivity (New Holland, 2018).

Until the end of 2019, Lesprojekt sluzby, s.r.o. (Ltd.), based in the Czech Republic, will work together with ZETOR TRACTORS a. s. company on the "DataBio" EU project, which is an application of telemetry and precision farming to tractors (Zetor, 2018). FarmTelemetry (www.farmtelemetry. eu), the project of Lesprojekt služby, s.r.o., provides an innovative solution to support farmers in the management of their farming actions. Moreover, it reduces the energy consumption, improves carbon balance and maintains high level of outputs. This project empowers farmers and companies to choose the right decisions and timely optimize the level of farm inputs by using its competitive edge (Farmtelemetry, 2018).

According to Bögel (2017), great potential is arising from the use of high-technology in modern agriculture as drones and sensor can collect and submit real time data, process this data and design advanced models and make recommendations to farmers through mobile devices of through robots which allow for immediate implementation.

\section{Motivations and drivers for smart servitization}

Many authors discussed the motivations of manufacturers undertaking servitization. These motivations are based on Wise and Baumgartner (1999). Oliva and Kallenberg (2003) divided the motivations into three main categories: competitive motivations, demand-based motivations and economic motivations. Also, Baines et al. (2009) suggest a typology based on: strategic (competitive), marketing (demand-based) and financial (economic) motivations.

Table 1 shows motivations and drivers for servitization based on current literature as described by Raddats et al. (2016).

Analysis of the private data performed by Grubic et al. (2011) indicated those factors that are driving companies to develop and adopt diagnostic and prognostic technology. The main factors driving manufacturers to develop and adopt diagnostic and prognostic technology are following ones:

- improving product performance,

- improving availability,

- improving maintenance efficiency and effectiveness,

- and differentiating from competitors' products.

The above-mentioned factors can be related to manufacturer's competitive strategy rather than to the need for regulatory compliance

\begin{tabular}{|c|c|c|c|}
\hline Driver & Source(s) & Explanation of driver & $\begin{array}{l}\text { Motivation } \\
\text { for servitization } \\
\text { (Oliva and } \\
\text { Kallenberg, 2003) }\end{array}$ \\
\hline Product differentiation & Mathieu (2001) & $\begin{array}{l}\text { Creates a stronger value proposition than } \\
\text { products alone }\end{array}$ & Competitive \\
\hline Cost savings & Araujo and Spring (2006), & $\begin{array}{l}\text { Saving the customer money in terms } \\
\text { of product ownership }\end{array}$ & Demand based \\
\hline Improved service quality & $\begin{array}{l}\text { Araujo and Spring (2006); } \\
\text { Fischer et al. (2012) }\end{array}$ & $\begin{array}{l}\text { Improvements in customer operational } \\
\text { processes }\end{array}$ & \\
\hline Risk reduction & $\begin{array}{l}\text { Baines and Lightfoot } \\
\text { (2014) }\end{array}$ & $\begin{array}{l}\text { Sharing new technology introduction } \\
\text { and operational performance risk }\end{array}$ & \\
\hline New revenue stream & Mathieu (2001 & $\begin{array}{l}\text { Services provide incremental revenue } \\
\text { to product revenue }\end{array}$ & Economic \\
\hline Stabilize revenue & $\begin{array}{l}\text { Gebauer and Fleisch } \\
(2007) \text {; Slack (2005) }\end{array}$ & $\begin{array}{l}\text { Services revenue less liable to fluctuate } \\
\text { than product revenue }\end{array}$ & \\
\hline Increased profitability & $\begin{array}{l}\text { Oliva and Kallenberg } \\
(2003)\end{array}$ & $\begin{array}{l}\text { Higher profitability attributable to service } \\
\text { activities }\end{array}$ & \\
\hline New service business model & $\begin{array}{l}\text { Kowalkowski (2014); } \\
\text { Spring and Araujo (2009) }\end{array}$ & $\begin{array}{l}\text { Manufacturers able to develop service } \\
\text { offerings that replace product offerings }\end{array}$ & \\
\hline
\end{tabular}

Source: adjusted according to Raddats et al., 2016

Table 1: Motivations and drivers to servitize. 
and safety. According to Grubic et al. (2011), about 70 percent of companies link higher and sustained revenues to adoption, 84 percent of companies consider servitization as a tool to strengthen relations with customers while allowing for a better recognition of their needs. By adopting this technology, manufacturers expect their customers to benefit from reduced total cost of ownership and increased availability. Consequently, it should lead to a reduction of risks and a better focus on key competencies. Grubic et al. (2011) also attribute the adoption and development of diagnostic and prognostic technology to the ever-rising rivalry on the market. Additionally, value propositions of equipment availability, risk reduction, and total cost of ownership are at the centre of attention. Therefore, diagnostic and prognostic technology can be considered an important enabler of servitization and no longer a cost of doing business.

Farmers want smart services to connect their tractors and implements to the Internet for a better understanding of agricultural operations and demand a personalized everyday working plan, which is based on data analysis from previous work shifts. For them is also essential to gather and analyse gained data. The important data in agriculture could be temperature, humidity and pressure of tractor environment and data related to clarify root causes and failure rates (Cedeño et al., 2018).

The aim of the paper is to determine why manufacturing companies have started to provide smart services with their products.

\section{Materials and methods}

There is a lack of knowledge about how smart services are used in praxis by manufacturing companies. As Wünderlich et al. (2015) recapitulate, "Despite the accelerating development of these smart services, academic research is still in its infancy. We see the need to further explore the effect that smart service has on organizations, customers and the evolving service landscape" (Wünderlich et al., 2015). In addition, the majority of existing research is based on case studies (e. g. Brax and Jonsson, 2009; Neu and Brown, 2005; Oliva and Kallenberg, 2003) and these case studies should be accompanied by quantitative, surveybased analysis across a sample of manufacturing companies (Gebauer and Kowalkowski, 2012; Neu and Brown, 2005). Hence, academics might focus their research as well on digital servitization in order to create a greater diversity, which will lead to increased value (Paschou et al., 2017).

Compared to the other European countries, the industrial sector still domains the economy in the Czech Republic. To learn more about smart services in manufacturing in the Czech Republic, the empirical part of the research included qualitative case studies which were conducted in a form of semi-structured interviews. The whole research focused on unfolding how are smart services provided by manufacturers nowadays. The interviews targeted the following areas: type of smart products and smart services, the length and way of smart service provision, customer perception of smart services, the reasons for starting with smart service provision, the benefits gained from smart services, barriers connected to smart service provision, gathering and using the data gained from smart services, specifics of Czech industrial market, collaboration with other firms and "learnings" for other firms which want to start with smart services.

In comparison with a single case approach, the multi-case approach provides more possibilities for analysis by allowing comparison and contrast of the results to point out specifics of each case and some generalization. For the purpose of this paper, the part of the study focused on the main reasons for commencing with smart service provision among the case companies was used.

\section{Context of the research}

The aim was to select companies within the same industry but in different stages of smart service provision. Purposive sampling was used to choose the companies Seven companies participating in the research were electrotechnical producers who operate in the same industry but supply a lot of products and services to their customers with different degrees of service orientation. The respondents recruited from directors or managers of the case companies.

All case companies have been implementing smart services to their offers at different levels and ranges, which provides valuable information about smart services in different contexts. Following are the main smart services provided by the case companies: remote monitoring, control and diagnostics, remote repairs, preventive and predictive maintenance. Three companies were selected from the members of the Electrotechnical Association of the Czech Republic (https://www.electroindustry.cz/). Four companies were detected from previous research 
conducted among sixty electrotechnical SMEs in the Czech Republic, South Moravian Region (CZ-NACE 26 and CZ-NACE 27) in 2014. A part of the research conducted in 2014 focused on services in manufacturing) contributed to the current knowledge with insights into service offering of electrotechnical manufacturing companies. The research was important not only to learn about the current situation of service offering in electrotechnical companies but was also essential for discovering companies providing smart services to their customers.

For the purpose of this research, another case company was added. This eighth case company was a larger manufacturer of tractors and it was chosen to provide a perspective on the current situation in smart services in a different industry. Seven small and medium companies were chosen from electrotechnical companies to present huge variety of their products, services and evaluation of smart services. Further, one case company producing tractors and front loaders, was chosen for the research also. Due to a number of employees and the typical characteristics of products (tractors and other agriculture equipment, which are still needed in agriculture sector) participated in our qualitative research only one manufacturer from another industry. Farmers operate in unique and ever-changing context and conditions and thus their participation in innovation efforts is desirable. As Bögel (2017) informs, the EU launched the European Innovation Partnership for Agricultural Productivity and Sustainability (EIP-AGRI) and supports the bottom-up approach to innovations. This program provides a common platform for farmers, researchers, business and other stakeholders and allows them to work closely together on finding solutions to joint problems and sharing the results.

Despite the fact that current literary sources have outlined generic motivations for servitization (Baines et al., 2009), not a great number of studies have yet focused on whether the motivations differ between various types of manufacturers. To give an example, Neu and Brown's (2005) study of servitisation within IT companies reveals the motivations relevant to this sector but do not attempt to generalise the motivations to other sectors. Similarly, Fischer et al. (2012) inform about generic motivations for the capital goods sector and describe motivations to servitize as a decision to "defend" the existing product business or "grow" into new services markets. This research therefore seeks to determine possible drivers behind the beginning of smart servitization and present some categories of drivers from the current manufacturers' perspective. The details of all case companies mentioned in this paper are listed in Table 2.

\begin{tabular}{|c|l|c|c|}
\hline Firm & Respondents & $\begin{array}{c}\text { Number } \\
\text { of employees }\end{array}$ & $\begin{array}{c}\text { The length } \\
\text { of smart service } \\
\text { provision } \\
\text { in years }\end{array}$ \\
\hline A & Owner & 15 & 1 \\
\hline B & Product Manager & 50 & 1 \\
\hline C & Owner & 10 & 2 \\
\hline D & Owner & 4 & 2 \\
\hline E & Owner & 25 & 2 \\
\hline F & Owner & 148 & 2 \\
\hline G & Product Manager & 170 & More than 2 \\
\hline H & R\&D Manager & 680 & 2 \\
\hline
\end{tabular}

Source: authors

Table 2. Case company description.

\section{Data collection and analysis}

The data were collected through in-depth interviews with owners or with top managers in the case companies. The interviews were conducted among the case companies from April 2017 to March 2018. The length of the interview ranged from 50 to 100 minutes. As they were performed on site, the interviewer was able to tour the company and get familiar with the company's environment. The informants were assured that no identifying information would be provided when the findings are presented. The majority of faceto-face interviews was recorded and transcribed. The themes were predefined, and the semi-structured interview contained open-ended questions.

The data analysis was performed followed an abductive analysis process, where the literature investigation laid the foundation for early interviews, which then used developing themes to track important issues as the interviews progressed and the understanding of smart services in the real-life setting increased (Dubois and Gadde, 2014). Open coding was used to organize the data and converting them to discrete thematic blocks. As qualitative case research is sensitive to researchers' subjective explanations, some peer consultations was necessary to decrease researcher bias and to increase the objectivity of the study. A rich set of direct interview quotations to demonstrate interpretations was added to support the transparency and conformability of the findings.

The study of literature laid the foundation for first interviews. Based on the data gathered 
through these interviews, themes were identified and developed in a form of open-ended questions. As the interviews progressed, the understanding of smart service provision in the business environment. Data analysis was performed using open coding to organize the data and converting them to discrete thematic blocks. As qualitative case research is sensitive to researchers' subjective explanations, some peer consultations was needed to avoid researcher bias and to ensure greater objectivity of the study. Therefore, the authors include multiple citations to better illustrate the findings and to secure the transparency and conformability.

\section{Results and discussion}

The case studies aim to analyze the current situation of smart service provision in manufacturing companies. One section of the research study was focused on finding the drivers behind smart servitization in manufacturing companies. A research question was formulated: Why have manufacturing companies started to provide smart services to their products? To answer the RQ, following contextual questions were prepared: (a) Who has initiated the beginning of smart servitization in manufacturing companies? (b) What are the drivers of smart servitization in manufacturing companies? The findings are presented below along with some quotes which help to illustrate the findings.

(a) Who has initiated beginnings of smart servitization in manufacturing companies?

In six case companies, the main initiative to start with smart service provision arose from the company itself. One case company has started because of their customers and another one because of their competitors. The findings are placed in the Table 3.

\begin{tabular}{|l|l|l|l|l|}
\hline Firm & A & B & C & D \\
\hline Activity of... & customers & company & company & company \\
\hline Firm & E & F & G & H \\
\hline Activity of... & company & company & competitors & company \\
\hline
\end{tabular}

Source: authors

Table 3: Activity to start with smart service provision.

The findings, placed in the Table 3, show three "active" subjects and three types of motivations by Oliva and Kallenberg (2003). Therefore, it is possible to say that activity of customer is demand based motivation, activity of company could be economic motivation and activity of competitor is competitive motivation.

(b) What are the drivers of smart servitization in manufacturing companies?

Many different drivers or reasons for staring with smart service provision were identified by the case companies during the interviews, including better flexibility, costs and time savings, better product reliability, higher sales and profits, an increase in customer satisfaction, etc. However, seven out of eight respondents mentioned a competitive advantage to be the driver as it could be also gained through the use of smart services. Three case companies mentioned that smart services are seen as one of the current market trends and must be incorporated to company activities. For the findings, see Table 4.

\begin{tabular}{|c|c|}
\hline Firm & Drivers \\
\hline A & $\begin{array}{l}\text { Improve situation on the market, increase } \\
\text { competitive advantage, better work with the data } \\
\text { for product innovation }\end{array}$ \\
\hline B & $\begin{array}{l}\text { Better product diagnostics, create competitive } \\
\text { advantage, better promotion of solution }\end{array}$ \\
\hline $\mathrm{C}$ & $\begin{array}{l}\text { Product differentiation such as current trend, } \\
\text { improve competitive advantage against large } \\
\text { companies, better flexibility }\end{array}$ \\
\hline $\mathrm{D}$ & $\begin{array}{l}\text { Essential part of our lives, better data using } \\
\text { for monitoring, analyzing and diagnostics }\end{array}$ \\
\hline $\mathrm{E}$ & $\begin{array}{l}\text { Use big potential of the gained data, increase } \\
\text { competitive advantage, time and costs savings } \\
\text { for customers, better product reliability }\end{array}$ \\
\hline $\mathrm{F}$ & $\begin{array}{l}\text { Differentiating from competitor's products, increase } \\
\text { profitability, better product reliability, increase } \\
\text { of operation security }\end{array}$ \\
\hline G & $\begin{array}{l}\text { Differentiating from competitor's products, increase } \\
\text { profitability, new revenue stream as a trend, better } \\
\text { facilitating of maintenance, costs and time savings }\end{array}$ \\
\hline $\mathrm{H}$ & $\begin{array}{l}\text { Be part of current trend, improve competitive } \\
\text { advantage, provide product differentiation, improve } \\
\text { product innovation }\end{array}$ \\
\hline
\end{tabular}

"We had to start with smart service provision. Smart services were a crucial condition for one tender in the past, where we wanted to participate. We had not provided them before, so we could not be involved."

"I perceive smart services a natural part of today's world. The data are very valuable and could change products so much. It is important to use the data. It is a necessity for our future."

"Essential part of our lives."

"Smart services are the competitive advantage of SMEs against large companies." 
"Smart services were something new and unknown in the beginning. We saw their big potential."

"Smart services definitely help us."

"Smart services have many advantages also for our customers."

The qualitative research has focused on the problems related to the reasons for starting with smart service provision. The research was conducted among eight manufacturing companies (seven electrotechnical companies and one manufacturer of tractors) in the Czech Republic, South Moravian Region. A research question (RQ) was formulated for the purpose of the research to find out why the companies have started to offer smart services to their products. The case studies investigated the situation in eight firms to receive an answer to the research question presented in this paper.

\section{Theoretical Implications}

Smart services based on smart products discussed in the paper are a very innovative topic, which is quite new in the research field and still open to further investigations. According to the research mentioned in this paper, six case companies (out of eight participating companies) have started with smart service provision based on their own decision. One case company has started with smart service provision because of their customers' demand and another one due to their competitors. An increasing number of physical items, tools, machinery and devices is now supplied with electronics, and enable computing and communication.

Many drivers for the onset of smart service provisions were identified by the case companies during the in-depth interviews in manufacturing companies. Nevertheless, seven out of eight respondents stressed the competitive advantage. In their opinions, the main driver behind beginning with smart service provision is to gain competitive advantage. The paper determinate possible drivers of smart servitization and present some categories of drivers in the Figure 1. Categories of drivers were distributed to the main five areas, such as: competitive advantage, current trends, data, finance and product. The Figure 1 is based on the findings from the research in eight manufacturing companies. The figure provides a better insight into the problems of smart service provisions and their drivers of current manufacturers.

The arrows to one category of drivers (competitive advantage) is bolder than to another four arrows (trend, data, finance and product) because of their frequency in respondents 'answers. In fact, all four categories make for competitive advantage.

As Fischer et al. (2013) mention, even manufacturers in high-technology sectors as well as those focused on product innovation are facing great difficulties and challenges when trying to differentiate their tangible products alone. This is a result of low-cost competitors' strategies who set very low prices of tangible products in order to gain market share. Economic motives could be essential considering the corporate focus change from product to services. Further, such change is perceived crucial for economic success.

\section{Managerial Implications}

The findings illustrate the reasons why to start with smart service provision in manufacturing companies. Three quarters of respondents decided to start with smart service provision upon their own decision and have already made first steps to implement smart services. The company is to decide whether or not to provide smart services. But first and foremost, the company needs to be clearly willing to offer them. The company may often be pushed by various circumstances, most frequently by their competitors and/or by the customers. Nevertheless, the company itself must openly incline towards this new possibility

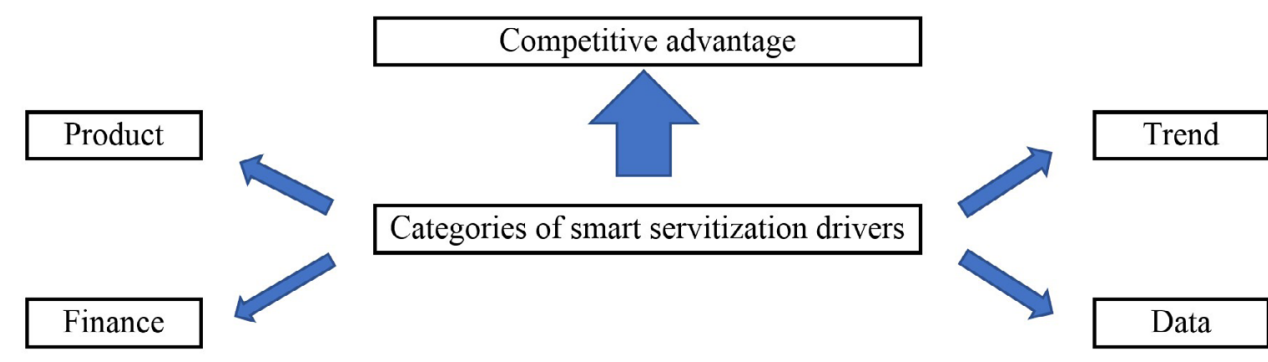

Source: authors

Figure 1. Categories of smart servitization drivers for manufacturers. 
and opportunity to exploit the potential of smart service provision. Following are the key benefits of remote monitoring technology for the manufacturers: improved performance and availability of their products, cost reduction, insight into customer needs and feedback for R\&D (Grubic, 2011).

According to the findings presented in the paper, the initial idea to start with smart services is connected to gaining possible competitive advantage. However, also other drivers were mentioned and are also considered important. Usually a combination of more drivers led to smart service provision (see Table 3 ). The respondents pointed out at least three different drivers and not only one. This is an important conclusion as it allows a more complex perception of the problems of smart services. Manufacturers have to see the benefits of smart servitization.

Findings show that manufactures usually decide by themselves to start with smart servitization, but the main categories of smart servitization drivers are connected to competitive advantage. Findings mentioned by Grubic (2011) imply that industry has positive expectations about the potential of remote monitoring technology. Remote monitoring technology does not only support existing value propositions but also enables new business models and service innovations. Once the companies perceive the benefits, it is much easier for them to start with change towards smart servitization. Nevertheless, the rather limited number of cases considered in this study do not allow a consistent generalization of the findings. Therefore, it may be useful to prepare a quantitative research to find out in depth about the main reasons and to try to discover some relations in the answers of the respondents.

Despite the fact that there is a great number of companies using remote monitoring technology enabling them to advance their services, these have not been properly recorded and described in more detail to ascertain the common practice in the area of servitized strategies (Grubic, 2011). Smart services are the future of manufacturing according to the respondents. Today's manufacturers recognize smart services as a possible competitive advantage. However, smart services will be a necessity in the close future.

\section{Conclusion}

Digitalization managed to raise efficiency, productivity and profitability in many industries. The new technologies and tools will influence directly and indirectly the development of manufacturing, including agriculture. Many stakeholders, large and small companies, research and development centers realize the opportunity and contribute to the digital development (Bögel, 2017). In the field of agriculture, precision agriculture put the industry on a new development trajectory, pushing ahead efficiency and productivity thresholds. Gains in yields will more depend on innovating in context, datafication of key factors, statistical analysis and decision-support algorithms (Bögel, 2017). The paper explores current situation in manufacturing companies which provide smart services to their clients, with the focus on the reasons why to start with smart service provision. To reach the research objective and answer the research questions, a qualitative multi-case study was conducted among eight $\mathrm{Czech}$ manufactures which have already started with smart service development.

The findings revealed that the manufactures usually decide by themselves to start with smart servitization, but the main categories of smart servitization drivers are connected to competitive advantage. This paper contributes to better understanding why today's manufacturing companies have started to provide smart services. Based on the case studies findings, the first implications for practice and theory were drawn. However, the study presented in this paper is still in the initial phase. The number of cases limitates a consistent generalization of achieved findings. The findings will be confirmed by further investigations.

The case studies methodology to analyze the "smart servitization" is overwhelmed, while very few theory building contributions were found (Paschou et al., 2017). While case studies may be very important in order to align academia and industry, it is necessary to stimulate more effort to develop and propose conceptual and theoretical works. A real digital servitization theory has still to come. That theory can also be built through well-designed surveys that have also the advantage of achieving a possible generalization of the results (Paschou et al., 2017). Although the study presented in this paper is still in the initial phase and a more in-depth research is needed before profound conclusions are made, first implications for practice and theory are drawn. However, the number of research cases is limited and does not allow a consistent generalization. As Paschou et al. (2017) notes that even though there is a great number of case studies analysing "smart servitization", a true smart servitization theory has not yet been designed. Moreover, not only is it important to align academia 
and industry through multiple case studies, it is equally important to stimulate more effort to develop and propose conceptual and theoretical works. According to Paschou et al. (2017), this could be achieved through well - designed surveys which can result in a possible generalization of the findings.

Corresponding authors

Ing. Lucie Kaňovská, Ph.D.

Institute of Management, Faculty of Business and Management

Brno University of Technology, Kolejní 2906/4, 61200 Brno, Czech Republic

E-mail:kanovska@fbm.vutbr.cz

\section{References}

[1] Allmendinger, G. and Lombreglia, R. (2005) "Four strategies for the age of smart services", Harvard business review, Vol. 83, No. 10, pp. 131. ISSN 0017-8012.

[2] Baines, T. S., Lightfoot, H. W., Benedettini, O., and Kay, J. M. (2009) "The servitization of manufacturing: A review of literature and reflection on future challenges", Journal of manufacturing technology management, Vol. 20, No. 5, pp. 547-567. ISSN 1741-038X. DOI 10.1108/17410380910960984.

[3] Baines, T. and Lightfoot, H. W. (2013) "Servitization of the manufacturing firm: Exploring the operations practices and technologies that deliver advanced services", International Journal of Operations \& Production Management, Vol. 34, No. 1, pp. 2-35. ISSN 0144-3577. DOI 10.1108/IJOPM-02-2012-0086.

[4] Beverungen, D., Matzner, M. and Janiesch, C. (2017) "Information systems for smart services", Information Systems and e-Business Management, vol. 15, No. 4, pp. 781-787. E-ISSN 1617-9854, ISSN 1617-9846. DOI 10.1007/s10257-017-0365-8.

[5] Bögel, G. (2017) "Competing in a smart world: the need for digital agriculture", In: "Management and Organization: Concepts, Tools and Applications", pp. 11-28. [Online]. Available: http://real.mtak.hu/54836/1/12_Management_and_Organization-Pearson2017j\%C3\%BAn08-DOI_CrossRef-2017j\%C3\%BAn13f.pdf. [Accessed: 20. May 2018]. DOI 10.18515/dBEM.M2017.n02.ch01.

[6] Borgmeier, A. (2002) "Schlußbetrachtung“, In: "Teleservice im Maschinen-und Anlagenbau". Deutscher Universitätsverlag, pp. 209-217. DOI 10.1007/978-3-322-81064-9.

[7] Brase, T. (2006) "Precision Agriculture", Delmar Cengage Learning, Independence, Kentucky.

[8] Brax, S. A. and Jonsson, K. (2009) "Developing integrated solution offerings for remote diagnostics: A comparative case study of two manufacturers", International Journal of Operations \& Production Management, Vol. 29, No. 5, pp. 539-560. ISSN 0144-3577. DOI 10.1108/01443570910953621.

[9] Cedeño, J. M. V., Papinniemi, J., Hannola, L. and Donoghue, I. (2018) "Developing smart services by internet of things in manufacturing business", LogForum, Vol. 14, No. 1., E-ISSN 1734-459X, ISSN 1895-2038. DOI 10.12783/dtetr/icpr2017/17680.

[10] Chatterjee, A., Greenberg, J., Jones, M., Kaas, H. W. and Wojcik, P. (2001) "Telematics: decision time for Detroit", London Business School Review, Vol. 12, No. 2, pp. 21-38. E-ISSN 2057-1615. DOI 10.1111/1467-8616.00172.

[11] Dubois, A. and Gadde, L. E. (2014) "Systematic combining - A decade later", Journal of Business Research, Vol. 67, No. 6, pp. 1277-1284. ISSN 0148-2963. DOI 10.1016/j.jbusres.2013.03.036.

[12] Farmtelemetry (2018) "Farmtelemetry Solution". [Online]. Available: http://www.farmtelemetry.eu/ [Accessed: 20.4.2018]. 
[13] Fischer, T., Gebauer, H. and Fleisch, R. (2012) "Service Business Development: Strategies for Value Creation in Manufacturing Firms", Cambridge University Press, Cambridge. DOI 10.1017/CBO9781139136730.

[14] Garcia, E., Guyennet, H., Lapayre, J. C. and Zerhouni, N. (2004) "A new industrial cooperative tele-maintenance platform", Computers \& Industrial Engineering, Vol. 46, No. 4, pp. 851-864. ISSN 0360-8352. DOI 10.1016/j.cie.2004.05.019.

[15] Gebauer, H. and Kowalkowski, C. (2012) "Customer-focused and service-focused orientation in organizational structures", Journal of Business \& Industrial Marketing, Vol. 27, No. 7, pp. 527-537. ISSN 0885-8624. DOI 10.1108/08858621211257293.

[16] Grubic, T., Redding, L., Baines, T. and Julien, D. (2011) "The adoption and use of diagnostic and prognostic technology within UK-based manufacturers", Proceedings of the Institution of Mechanical Engineers, Part B: Journal of Engineering Manufacture, Vol. 225, No. 8, pp. 1457-1470. DOI 10.1177/0954405410395858.

[17] Grubic, T. and Jennions, I. (2017) "Remote monitoring technology and servitised strategies-factors characterising the organisational application", International Journal of Production Research, Vol. 56, No. 6, pp. 2133-2149. E-ISSN 1366-588X, ISSN 0020-7543. DOI 10.1080/00207543.2017.1332791.

[18] Hallová, M., Polakovič, P. and Slováková, I. (2017) "Current Trends in Training of Managers in the Field of Information and Communication Technologies and Identifying the Barriers to Education of Managers", AGRIS On-line Papers in Economics and Informatics, Vol. 9, No. 4, pp. 45-52. ISSN 1804-1930. DOI 10.7160/aol.2017.090405.

[19] Hermann, M., Pentek, T. and Otto, B. (2016) "Design principles for industrie 4.0 scenarios", System Sciences (HICSS), $49^{\text {th }}$ Hawaii International Conference on. IEEE. DOI 10.1109/HICSS.2016.488.

[20] John Deere (2018) “Telematics” [Online]. Available: https://www.deere.com/en/electronic-solutions/ telematics/ [Accessed: 15.3.2018].

[21] Kiritsis, D. (2011) "Closed-loop PLM for intelligent products in the era of the Internet of things", Computer-Aided Design, Vol. 43, No. 5, pp. 479-501. ISSN 0010-4485. DOI 10.1016/j. cad.2010.03.002.

[22] Klein, M. M. (2017) "Design Rules for Smart Services: Overcoming Barriers with Rational Heuristics", Doctoral dissertation, Universität St. Gallen, Switzerland.

[23] Levrat, E., Iung, B. and Marquez, C. A. (2008) "E-maintenance: review and conceptual framework", Production Planning \& Control, Vol. 19, No. 4, pp. 408-429. E-ISSN 1366-5871, ISSN 0953-7287. DOI 10.1080/09537280802062571.

[24] Lim, C. H., Kim, M. J., Heo, J. Y. and Kim, K. J. (2015) "Design of informatics-based services in manufacturing industries: case studies using large vehicle-related databases", Journal of Intelligent Manufacturing, Vol. 29, N. 3, pp. 497-508. E-ISSN 1572-8145, ISSN 0956-5515. DOI 10.1007/s10845-015-1123-8.

[25] Lightfoot, H., Baines, T. and Smart, P. (2013) "The servitization of manufacturing: A systematic literature review of interdependent trends", International Journal of Operations \& Production Management, Vol. 33, No. 11/12, pp. 1408-1434. ISSN 0144-3577. DOI 10.1108/IJOPM-07-2010-0196.

[26] Marquardt, K. (2017) "Smart services-characteristics, challenges, opportunities and business models", In: Proceedings of the International Conference on Business Excellence, De Gruyter Open, pp. 789-801. ISSN 2558-9652. DOI 10.1515/picbe-2017-0084.

[27] National Instruments (2018) "Learn how to implement the Industrial IoT at a one-day industry event" (seminar), Brno.

[28] Neu, W. A. and Brown, S. W. (2005) "Forming successful business-to-business services in goods-dominant firms", Journal of Service Research, Vol. 8, No.1, pp. 3-17. E-ISSN 15527379, ISSN 10946705. DOI 10.1177/1094670505276619. 
[29] New Holland (2018) "Telemetry system". [Online]. Available: http://www.agriexpo.online/prod/ new-holland/product-169826-2253.html. [Accessed: 25.3.2018].

[30] Oliva, R. and Kallenberg, R. (2003) "Managing the transition from products to services", International Journal of Service Industry Management, Vol. 14, No. 2, pp. 160-172. ISSN 0956-4233. DOI 10.1108/09564230310474138.

[31] Paschou, T., Adrodegari, F., Perona, M. and Saccani, N. (2017) "The digital servitization of manufacturing: a literature review and research agenda", $27^{\text {th }}$ RESER Conference Bilbao [Online]. Available: https://www.researchgate.net/publication/319628925_The_digital_servitization_of_ manufacturing_a_literature_review_and_research_agenda [Accessed: 20 A pril 2018].

[32] Raddats, C., Baines, T., Burton, J., Story, V. M. and Zolkiewski, J. (2016) "Motivations for servitization: the impact of product complexity", International Journal of Operations \& Production Management, Vol. 36, No. 5, pp. 572-591. ISSN 0144-3577. DOI 10.1108/IJOPM-09-2014-0447.

[33] Rowly, J. (2006) "An analysis of the e-service literature: towards a research agenda", Internet research, Vol. 16, No.3, pp. 339-359. ISSN 1066-2243. DOI 10.1108/10662240610673736.

[34] Rust, T. R. and Huang, M.-H. (2014) "The service revolution and the transformation of marketing science", Marketing Science, Vol. 33, No. 2, pp. 206-221. E-ISSN 1526-548X, ISSN 0732-2399. DOI $10.1287 / \mathrm{mksc} .2013 .0836$.

[35] Šilerová, E., Hennyeyová, K., Michálek, R., Kánská, E., and Jarolímek, J. (2017) "Influence of the Correct Management of the IT Department on the Quality of Data and Information Processing", AGRIS On-line Papers in Economics and Informatics, Vol. 9, No. 4, pp. 91-98. ISSN 1804-1930. DOI 10.7160/aol.2017.090409.

[36] Valtra (2018) " Systém Valtra Connect" (In Czech). [Online]. Available: http://www.valtra.cz/Systeacutem-Valtra-Connect_9935.aspx [Accessed: 20 April 2018].

[37] Wünderlich, N. V., Heinonen, K., Ostrom, A. L., Patricio, L., Sousa, R., Voss, C. and Lemmink, J. G. (2015) "Futurizing" smart service: implications for service researchers and managers", Journal of Services Marketing, Vol. 29, No. 6/7, pp. 442-447. ISSN 0956-4233. DOI 10.1108/JSM-01-2015-0040.

[38] Zetor (2018) "Výzkumná činnost a granty" (In Czech). [Online]. Available: https://www.zetor.cz/ vyzkumna-cinnost-a-granty [Accessed: 26.2.2018].

[39] Zhang, N., Wang, M. and Wang, N. (2002) "Precision agriculture - a worldwide overview", Computers and electronics in agriculture, Vol. 36, No. 2-3, pp. 113-132. ISSN 0168-1699. DOI 10.1016/S0168-1699(02)00096-0. 